Published As:

Chaimov, T. A., Barazangi, M., Al-Saad, D., Sawaf, T., and Gebran, A. Crustal shortening in the Palmyride fold belt, Syria, and implications for movement along the Dead Sea fault system. Tectonics, 9, 1369-1386, 1990.

\title{
CRUSTAL SHORTENING IN THE PALMYRIDE FOLD BELT, SYRIA, AND IMPLICATIONS FOR MOVEMENT ALONG THE DEAD SEA FAULT SYSTEM
}

Thomas A. Chaimov and Muawia Barazangi

Institute for the Study of the Continents and Department of Geological Sciences, Cornell University, Ithaca, New York

Damen Al-Saad, Tarif Sawaf, and Ali Gebran

Syrian Petroleum Company, Ministry of Petroleum and Mineral Resources, Damascus

Abstract. The Palmyride fold belt is a northeast-trending, 400 by $100 \mathrm{~km}$ transpressive belt in central Syria embedded in the northern Arabian platform, bounded to the north by the Aleppo plateau and to the south by the Rutbah uplift. Palinspastically restored cross sections from three transects across the Palmyride fold belt demonstrate a minimum NW-SE shortening of about $20 \%$ or $20 \mathrm{~km}$ across the southwestern segment of the belt, diminishing to $1-2 \mathrm{~km}$ in the northeast, close to the Euphrates graben system. The cross sections are based on the 1:200,000 scale geologic map of Syria and previously unavailable seismic reflection and well data, all provided by the Syrian Petroleum Company. These results differ significantly from those predicted by kinematic models of Middle East plate motions. In western Syria and eastern Lebanon the Palmyrides obliquely intersect (at about $45^{\circ}$ ) the roughly north-trending Dead Sea transform fault system. The Dead Sea fault system shows well-documented evidence of $105 \mathrm{~km}$ of left-lateral displacement since mid-Tertiary time south of its intersection with the Palmyrides, yet only about $25 \mathrm{~km}$ of motion has been documented north of that juncture in Lebanon and western Syria. Thus, kinematic models of Middle East plate motions predict $80 \mathrm{~km}$ of shortening in Syria, most of which should be accommodated in the Palmyride fold belt. Several possibilities exist to explain the discrepancy between the $80 \mathrm{~km}$ of predicted shortening and the only $20 \mathrm{~km}$ of shortening measured from restored cross sections. Restored cross sections offer only minimum shortening estimates, so the calculated $20 \mathrm{~km}$ may underestimate shortening. Second, evidence of strike-slip displacement recognized in the field and reported in the literature, and indicated by new focal mechanism solutions of two recent earthquakes in the Palmyrides, indicates that some of the still "missing" displacement may be distributed throughout central and northern Syria as strike-slip motion oblique to the relative northward convergence of the Arabian plate on the Eurasian plate. Alternatively, previous estimates of slip along the northern segment of the Dead Sea transform fault system may be only minimum estimates. A final possibility is that the Dead Sea transform fault in northwestern Syria has been active for only the past 5-6 m.y. or so, implying that it was either nonexistent or moved only slightly before the Pliocene. This would suggest that there is a total of only $45 \mathrm{~km}$ of $\mathrm{N}-\mathrm{S}$ convergence to be found in central and northern Syria, about $25 \mathrm{~km}$ on the Dead Sea fault system and about $20 \mathrm{~km}$ in the Palmyrides. This last possibility requires that the northern and southern segments of the Dead Sea fault system developed independently during most of the past 15-20 m.y. In light of the documented but unquantified strike-slip motion in the Palmyrides, it seems reasonable that strike-slip motion does accommodate a significant portion of the convergence between the Arabian and Eurasian plates. It is likely, however, that one or more of the other proposed mechanisms also accounts for a component of the expected $80 \mathrm{~km}$ of shortening. 
Complex tectonic belts surround the Syria region (Figure 1a). To the north of Syria lies the Bitlis suture and the East Anatolian fault of southern Turkey, to the east the Zagros fold belt of Iran and Iraq. In Lebanon and western Syria lies the left-lateral Dead Sea transform fault system. These interrelated tectonic elements all place constraints on Palmyride evolution. Therefore, any tectonic history of the Palmyride belt must fit in with the tectonic framework of the whole region.

The Palmyride fold belt in central Syria trends northeast and is bounded to the north by the more stable Aleppo plateau and to the south by the Rutbah uplift, the northern margin of the stable Arabian platform (Figure 1b). Thickened Paleozoic and Mesozoic strata in the uplifted blocks of the Palmyrides indicate an inverted Upper Paleozoic and Mesozoic basin, perhaps an aulacogen [Ponikerov, 1966; Beydoun, 1981; McBride et al., 1990]. Tertiary deformation includes both north and south vergent oblique reverse and thrust faults, reactivated normal faults, broad as well as tight folds, and even Jura-type box folds. The Palmyrides can be subdivided into at least three distinct regions or blocks, two to the north of a major E-W trending strike-slip fault, the Jhar fault, and one more intensely folded block to the south of the fault (see Figure 1b). The broad folds are observed primarily in the Bilas and Bishri blocks to the north of the Jhar fault, giving those regions a more gently deformed appearance than the southwestern part. McBride et al. [1990] provide a thorough overview of the geologic and tectonic character of the belt and surrounding regions.

Palmyride tectonics are important for understanding the diffuse plate boundary between Asia and Arabia that extends for $300 \mathrm{~km}$ from the Palmyrides to the Bitlis suture. Many scientists have studied Middle East tectonics, especially the Dead Sea transform fault system, the Red Sea, and the Afar region [e.g., Quennell, 1958; Freund et al., 1970; Le Pichon and Francheteau, 1978; Hempton, 1987], but as yet little attention has been focused on the detailed tectonics of Syria. A few authors have, however, included the Palmyride belt in their studies of the region [e.g. Beydoun, 1981; Lovelock, 1984; Walley, 1988]. The Syrian Petroleum Company has made available to Cornell University seismic reflection and well data from Syria. These data have facilitated a concerted effort to understand the tectonics of Syria and their relation to surrounding tectonic features. The present study concentrates on data from the Palmyride intracratonic fold belt in central Syria.

Most balanced cross section studies are conducted in fold and thrust belts near the margins of continents in belts that formed as a direct result of plate collision. In the Palmyride case we apply the method of restoring balanced cross sections to estimate shortening in an intracontinental fold belt. The Palmyrides, where geological and geophysical data are plentiful, provide a unique opportunity to examine in detail the subsurface structure and tectonic history of an intracratonic mountain belt. Not only do balanced cross sections provide a basis from which shortening in the Palmyrides can be estimated, but the estimate itself may help explain an enigma of Middle East plate tectonics, the discrepancy between left-lateral offsets along the northern versus the southern segments of the Dead Sea transform fault system.

\section{DEAD SEA TRANSFORM FAULT SYSTEM}

A question that pervades the geologic literature of the Middle East region concerns the magnitude of left-lateral motion observed across the southern versus the northern segments of the Dead Sea transform fault system. The Dead Sea fault system, which strikes NNE-SSW in Lebanon and N-S in westernmost Syria, displays $\sim 105 \mathrm{~km}$ offset on its southern segment [Quennell, 1958; Freund et al., 1970], south of Lebanon. This amount of offset is generally accepted [Courtillot et al., 1987]. As yet, however, no one has unequivocally documented more than 20-30 km of left-lateral offset on the northern segment [Quennell, 1958; Trifonov et al., 1983; Vladimir Trifonov, personal communication, 1989]. The question arises, then, as to what has become of the missing $80 \mathrm{~km}$ of displacement.

The little-studied Palmyride belt in central Syria (Figure 1) strikes obliquely (about $30-45^{\circ}$ ) to the Dead Sea transform fault system, and its intersection with the Dead Sea transform fault system divides that system into its aforementioned northern and southern segments. It may hold the answer to the problem of discrepant offsets across the northern versus the southern segments of the transform fault system. If the Palmyrides alone accommodated the missing 80 
$\mathrm{km}$ solely by thrusting and folding one would expect to find evidence for large scale shortening in cross sections constructed across the belt. If, however, considerable strike-slip motion is invoked to accommodate some of the shortening one would expect to observe less thrusting and folding. Based on his kinematic model of the northeastern Mediterranean Quennell [1958] asserted that if the northern Dead Sea transform fault system moved independently of the southern segment, an important assumption on which he elaborates little, then $45 \mathrm{~km}$ of shortening should be apparent in the southwestern Palmyrides, diminishing to zero $400 \mathrm{~km}$ along strike to the northeast. Recent accelerated activity in exploration for hydrocarbons in Syria has resulted in the collection of much seismic and well data. Newly available seismic data in the region provide a medium for new structural interpretations and facilitate an estimate of shortening, thereby providing a quantitative test of Quennell's hypothesis.

\section{DATA AND METHOD OF ANALYSIS}

Seismic, well, and other relevant geologic information was provided for this study by the Syrian Petroleum Company. From nearly $1000 \mathrm{~km}$ of seismic data at Cornell, three transects through the Palmyride belt were selected for this study. The seismic data were collected and processed by a variety of oil companies over many years, so their quality varies. For the most part, however, the four to five second seismic profiles, nearly all processed paper copies, image well the thick Mesozoic and Cenozoic sedimentary section of central Syria. Data acquisition and/or processing problems were commonly encountered over unusually rugged terrain which often coincides with exposures of resistant Cretaceous carbonate rocks. Other seismic data problems are few and minor. Exploration wells in Syria range in depth from very shallow to over $4 \mathrm{~km}$. Well information from the three wells used in this study, the locations of which appear in Figures 1-4, consists primarily of formation tops picked by Syrian Petroleum Company geologists as well as sparse geophysical well logs. The interpretive cross sections presented, however, are based primarily on the seismic reflection sections. Integral to the interpretation of the seismic sections and for geologic extrapolation where seismic data were not available was Ponikerov's [1963] 1:200,000 scale geologic map of Syria.

Three $\sim 50 \mathrm{~km}$ long northwest-southeast transects which cross most of the Palmyride belt normal to strike were constructed from the seismic reflection profiles (see Figure 1b). The mostly high quality (to $\sim 3 \mathrm{sec}$ ) seismic sections were correlated with surface geology and well information. Several stratigraphic sequences on each time section were converted to depth using stacking velocities and formation tops from nearby wells. These units are, in ascending order, Paleozoic, Jurassic and Triassic, Cretaceous, Paleogene, and Neogene. The resultant cross sections were area balanced in order to maximize their "chance of being right" [Dahlstrom, 1969] and simultaneously restored to an undeformed state to estimate the shortening accommodated by thrust faulting and folding.

At times, in areas of complex structure where stratigraphic control was minimal, several different interpretations of the seismic data seemed plausible, but only one interpretation balanced upon restoration. For example, over the northwesternmost SW vergent anticline of transect A (see Plate 1) the Cretaceous section is continuous. This places strict limits on the amount of shortening interpreted in the poorly reflective Jurassic and Triassic section. Where an unbalanced duplex structure might appear to fit geometrically, the simple ramp/flat shown in Plate 1 balances.

The cross sections were balanced only as far north as the Jhar fault, north of which compressional structures are less pronounced. North of the steep, E-W striking Jhar fault strike-slip duplexing [Woodcock, 1986] is probably the dominant mode of uplift, where large, relatively undeformed uplifted crustal blocks are bounded by steep faults that evince negligible shortening. This separation of deformation styles is similar to the strain partitioning discussed by Mount and Suppe [1987] and Zoback et al. [1987] for the San Andreas system.

\section{RESULTS}

These new results enrich our understanding of Middle East tectonics, in particular the tectonics of Syria. They provide important information on the timing of deformation in Syria and the magnitude of shortening in the Palmyride fold belt. These data and interpretations also 
contrast the very different deformational styles within the belt, the southwestern thin-skinned style of deformation where a low-angle detachment is observed versus the northeastern thicker-skinned style where no detachment is apparent.

\section{Timing of Palmyride Deformation}

A general statement about the timing of compressional deformation in the Palmyrides can be made based on the data presented in this study. While it is difficult to determine from this data set the exact age of the onset of compression in the Palmyrides, it is accurate to say that most Palmyride shortening took place after the late Oligocene. This conclusion stems from the observation that the thick Paleogene (Paleocene through Oligocene) section throughout the Palmyrides varies very gradually in thickness in any given dip section (see for example, Figure 2 ), and it furthermore shows little evidence of internal onlap, suggesting relatively quiescent tectonics during deposition. In contrast, all of the numerous small Neogene (Miocene and Pliocene) basins in the region exhibit marked onlap, and some even downlap, suggesting active Neogene tectonism.

\section{Shortening}

Palinspastic reconstructions of cross sections based on seismic reflection data tied with well information and constrained by surface geology yield minimum crustal shortening values much lower than the expected $80 \mathrm{~km}$. An estimate of minimum total shortening for the three sections yielded from southwest to northeast $20 \mathrm{~km}, 3 \mathrm{~km}$, and about $1 \mathrm{~km}$, respectively. Plate 1 and Figures 2 and 3 show the three composite line drawings and their respective depthconverted cross sections in the deformed and undeformed states. Their locations are shown in Figure 1b. Stratigraphic picks on the cross sections are based on seismic character and only limited well data and so are only approximate.

The presence and absence of a detachment in Triassic (?) strata, possibly located along an evaporite bed, likely controls the vastly different deformational styles present in the southwestern versus the northeastern Palmyrides. The southwestern, most intensely folded region exhibits typical fold and thrust belt structures, with a very low-angle décollement surface probably in the lower (basal?) Triassic. Clear evidence of a low-angle detachment at this stratigraphic level is seen on the seismic reflection data only from the southwestern region. It is this detachment that is interpreted to correspond to an evaporitic layer. Figure 4 shows the best seismic example of the décollement in the southwest.

The strata of probable Paleozoic age below the décollement appear slightly curved. This phenomenon has been simply modeled as velocity pull up of a very gently dipping flat layer. A simple model based on a few major reflections was constructed using the Sierra Geophysics three dimensional seismic modeling package. The relatively undeformed Paleozoic strata can be modeled as a flat layer or, with a slight perturbation in seismic velocities as a very gently dipping horizon. Velocities used in the modeling were approximate due to the poorly constrained stacking velocities of the seismic section and the dearth of sonic well log information. Nonetheless, preliminary seismic modeling does indicate relatively undeformed sub-décollement strata. In the future a detailed study of the overlying deformed Mesozoic and Cenozoic seismic sequences will yield better constraints on the timing of deformation in the Palmyrides.

In the northeastern Palmyrides, where shortening is about an order of magnitude less, a basal Triassic evaporite is absent or not well developed. Figure 5 shows an example from the northeast of an anticline whose deformation involves almost the entire Phanerozoic column. The Doubayat-2 well penetrates to a total depth of $3614 \mathrm{~m}$ (about 2.0 seconds on the seismic section in Figure 5) not far from the top of Precambrian basement and records no faults in the section. Any detachment level in the northeastern region must lie deeper than the Doubayat well, which bottoms in the Ordovician.

In the southwest the presence of a décollement surface in the lower Triassic has important implications for hydrocarbon exploration in the Palmyrides. If a lower Triassic evaporite horizon decouples the overlying Mesozoic and Cenozoic sediments from the Paleozoic section where hydrocarbon potential is good [Ponikerov et al., 1967], structures in the Paleozoic need not mimic those in the Mesozoic and Cenozoic. Hence, particular care should be given to the 
processing of deeper (Paleozoic) seismic data, especially in the southwestern Palmyrides where a detachment clearly exists and Paleozoic strata are decoupled from overlying Mesozoic and Cenozoic strata.

Another important implication of the interpretation of a detachment is the necessity to continue the décollement northward beyond the northern end of the cross section, that is, north of the Jhar fault. The interpretation as presented in cross section A (Plate 1b) requires this northward extension of the décollement. It is unknown whether the décollement continues at the same stratigraphic level for hundreds of kilometers into southern Turkey where it meets the Bitlis suture, whether it ramps down deeper and eventually soles into the middle or lower crust, or whether it ramps up to the north, essentially decapitating the Aleppo plateau.

Most of the Palmyride shortening is accommodated in this southwestern region. $20 \mathrm{~km}$ of NW-SE shortening in southwestern central Syria (near Damascus) is clearly documented in the new cross sections. But the magnitude of shortening predicted by kinematic models was about $80 \mathrm{~km}$. There still remain $60 \mathrm{~km}$ of crustal shortening unaccounted for.

\section{DISCUSSION}

A variety of possibilities exists to explain the obvious discrepancy between the expected ( 80 $\mathrm{km})$ and observed $(20 \mathrm{~km})$ shortening values in the Palmyride belt. First, and least likely of the possibilities, is that the interpretive sections introduced in this study may not reflect actual shortening in Syria. It is well known that balanced and restored cross sections yield conservative estimates of shortening [e.g., Hossack, 1979]. It should be kept in mind that shortening estimates based on this data set, a small portion of that which exists in the region, are minimum estimates. Second, strike-slip faults in the Aleppo plateau and in the Palmyrides must accommodate at least some of the "missing" $60 \mathrm{~km}$ of expected crustal shortening, although, the apparent stability (lack of seismicity, subdued topography, and monotonous Paleogene outcrop) of the Aleppo plateau implies only minor tectonism there. A third possibility is that the estimates of $25 \mathrm{~km}$ of slip along the northern segment of the Dead Sea transform fault system are too low. The elaborate mapping of the area argues strongly against such an assertion. Finally, the original apparent $80 \mathrm{~km}$ discrepancy between northern and southern Dead Sea fault system offsets may be false. It is possible that during the first 10-15 m.y. of motion on the Dead Sea transform fault (about $60 \mathrm{~km}$ of strike-slip motion), the fault itself did not extend into what is now central Lebanon and northwestern Syria. In effect, this would mean that there really is no discrepancy, and that the $20-25 \mathrm{~km}$ of motion on the northern extension of the Dead Sea fault plus the $20-25 \mathrm{~km}$ shortening in the Palmyrides is all that exists in northern Syria. Each of these possibilities will now be examined in detail.

\section{Limitations of Balanced Sections}

Dahlstrom [1969] and others [e.g., Elliot, 1983; De Paor, 1988] detail the many assumptions implicit in constructing any balanced cross section across a fold and thrust belt, among them the assumptions of a regional décollement horizon, two-dimensional deformation, and constant bed thickness. Many "rules" of classic fold and thrust belts are violated by the Palmyride belt. First, no obvious regional detachment surface imaged by the seismic underlies the entire belt. In the Atlas mountains of Tunisia, a possible homolog to the Palmyrides, Snoke et al. [1988] also see no regional detachment, but rather reactivated normal faults. If this were the case in the Palmyrides, estimates of shortening based on balanced cross sections would be even lower than $20 \mathrm{~km}$ because steep reactivated normal faults cannot accommodate much shortening. Seismic data prove the existence of a detachment surface only in the southwestern Palmyrides.

Furthermore, both surface mapping and earthquake focal mechanisms document strike slip in the mountain belt. The most prominent mapped fault in the Palmyrides, and the northern limit of all three cross sections presented in this study, is the Jhar fault, a $170 \mathrm{~km}$ long steep fault that strikes roughly E-W and separates the southwestern Palmyride block from the Bilas and Bishri blocks. Judging from its linear continuity and steep dip, the Jhar likely has been a strike-slip fault. Actual magnitude of lateral offsets across the Jhar fault, however, are extremely difficult to quantify. Associated with other faults, two recent $\mathrm{m}_{\mathrm{b}} \sim 4.8$ earthquakes, one on October 5, 1970 and one on May 20, 1987, provide data on the present day sense of motion in the Palmyrides. Focal mechanisms from both events show that strike and reverse 
slip are still active in the Palmyrides. The focal mechanisms are based on all available up-todate data including that reported in the International Seismological Center and Preliminary Determination of Epicenters bulletins. Additional first motion polarity readings were obtained from World Wide Standardized Seismic Network records. A focal mechanism of the 1970 event was published in 1976 [Ben-Menahem et al., 1976], but was based on relatively limited observations from only a few seismic stations. Our new focal mechanisms indicate moderately steep $\left(\sim 70^{\circ}\right)$ SSE-dipping fault planes with an oblique sense of motion about equally divided between reverse and right-lateral strike-slip. The locations of the earthquakes and their associated fault plane solutions are shown in Figure $1 \mathrm{~b}$.

Surface mapping at a scale of 1:200,000 shows little if any evidence of strike slip in the study area, so strike-slip motion, while it is a factor in Palmyride deformation, is not of major concern in this study. The sections presented in this paper were constructed assuming twodimensional deformation. Three parallel cross sections were constructed along strike to allay concerns about this assumption. Since the three sections give mutually consistent results, i.e., they do not show that shortening varies in a random manner along strike, then the assumption of two-dimensional deformation here may not be a bad one. Furthermore, if NE-SW strike slip were the major control of the folds in the Palmyrides, one might expect to see unevenly thickened and thinned beds in a given section. No stretched strata have been observed.

Finally, deformation in the sedimentary section extends beyond the southern paleobasin margin as defined by the rapid thinning of Mesozoic strata, thereby further complicating the balancing process. For example, in cross section $C$ (Figure $3 b$ ) where the Jurassic and Triassic section thins markedly to the south indicating the margin of the Mesozoic basin, at least three small folds occur still farther south.

With all these complications in mind, the cross sections were balanced to the degree possible and restored. Strictly, the term retrodeformable is, in reference to these cross sections, more accurate than balanced [Suppe, 1985]. While balanced cross sections in thrust belts by definition restore to a minimum possible undeformed length [Hossack, 1979] it is difficult to imagine that the calculated $20 \mathrm{~km}$ shortening in the most strongly deformed southwestern region of the Palmyrides is a factor of four lower than actual shortening. If the Palmyrides were truly shortened by the expected $80 \mathrm{~km}$, then this implies that the now $100 \mathrm{~km}$ wide fold belt was once $180 \mathrm{~km}$ wide, and surely almost $50 \%$ shortening would give rise to a very prominent mountain belt. But the Palmyrides have on the average only a few hundred meters of relief. Because gravity modeling shows the crust beneath the Palmyrides to be of typical continental thickness, about $40 \mathrm{~km}$ [Best et al., 1990], simple volumetric calculations indicate that the crust would have to have been only $24 \mathrm{~km}$ thick prior to the postulated $80 \mathrm{~km}$ of shortening. Continental crust this thin would almost certainly be associated with shallow if not surface volcanics as are seen, for example, in the Basin and Range Province of the western United States where the crust is thin. With exposure of Jurassic through Holocene rocks, the conspicuous paucity of volcanics in the Palmyrides precludes such marked shortening. Minor occurrences of volcanic rocks have, however, been reported from a few wells.

These lines of evidence, the mutual consistency of the three cross sections, the good assumption of two-dimensional deformation in the study region, and the improbability of once very thin crust, all lend credence to the $20 \mathrm{~km}$ shortening estimate.

\section{Sideways Escape of Northern Syria}

Assuming that the shortening estimated here is correct suggests that some other mechanism is responsible for accommodating the expected $80 \mathrm{~km}$ of shortening. Strike-slip motion oblique to the cross sections may accommodate the remainder of the shortening, or at least a portion of it. Both mapped faults, the Jhar fault, for example, and earthquake focal mechanisms support this assertion.

Jackson and McKenzie [1988] review two end member ways in which the deformation between two converging plates takes place (see Figure 6). One end member is simple folding and thrusting in the direction of convergence as in the case of some regions in western North America. The other mode involves the sideways wedging out or squirting out of a relatively rigid continental block as summarized by Burke and Sengör [1986], for example, in the western Turkey case. This second mode requires strike-slip motion oblique to the direction of maximum shortening as well as essentially a free surface, for example, an oceanic/continental 
plate boundary, through which the continental block can escape. The northeast-trending Palmyride belt strikes approximately $45^{\circ}$ to the northward encroachment of the Arabian plate. An eastward escape model at first looks desirable in the north Syrian setting, with left-lateral motion along the Dead Sea and East Anatolian fault systems on the west and north, respectively, and possible right-lateral motion in the Palmyrides [Quennell, 1984], but northern Syria has no free surface to the east through which it can escape as western Turkey does. Indentation of the Euphrates graben northeastward along strike from the Palmyrides (see Figure 1a) is also not observed, so eastward escape of northern Syria as a single block from Arabia is not likely. Furthermore, a N-S component of $60 \mathrm{~km}$ of shortening would be manifest as over $80 \mathrm{~km}$ of strike slip in the NE-trending Palmyrides. There is no obvious evidence for this amount of strike slip on any one fault in the Palmyrides,although, considerable strike slip may be subtly distributed throughout the belt. While numerous vertical (probably strike-slip) faults dissect the Aleppo plateau to the north (Figure 7), the magnitude of displacement across them is unknown. While recent fault slip data indicate a right-lateral component in the Palmyrides, Walley [1988] offers a scenario whereby faults in the Palmyrides comprise a leftlateral braided strike-slip system that distributes the excess shortening throughout central and northern Syria (see Figure 8). Strike-slip motion plays at least a small role in shaping the Palmyride belt, and may account for over $30 \mathrm{~km}$ of northward Arabian motion in northern Syria [Walley, 1988]. The net sense and magnitude of strike-slip motion in the Palmyrides have yet to be well determined, and a thorough investigation of strike-slip motion in Syria is warranted.

\section{Uncharted Offsets on the Dead Sea Fault System}

Another viable possibility is that the estimates of about $25 \mathrm{~km}$ of left-lateral slip on the northern segment of the Dead Sea transform fault system are too low. Based on his kinematic model of Cenozoic eastern Mediterranean plate motions Quennell [1984] reported $30 \mathrm{~km}$ of displacement along one of the two major strands of the northern Dead Sea transform fault. Similarly Trifonov et al. [1983] and V. Trifonov (personal communication, 1989) document only 20-25 km of slip on the northern Dead Sea faults, based on offset mid-Miocene and younger volcanics and on a $0.5-0.6 \mathrm{~cm} / \mathrm{yr}$ slip rate calculated from carbon-dated Quaternary alluvium offsets. In particular, V. Trifonov (personal communication, 1989) cites offset of 5-6 m.y. old basalts. At a constant post-Miocene (post- 6 m.y.) rate of $0.5 \mathrm{~cm} / \mathrm{yr}$ this is in good agreement with the total $25 \mathrm{~km}$ offset. However, most of the recognized $105 \mathrm{~km}$ of left-lateral motion on the southern segment of the Dead Sea transform fault occurred during the past 20 m.y. [Quennell, 1958 and many others]. Hypothesizing a minimum pre-Pliocene (pre-6 m.y.) slip rate of $0.5 \mathrm{~cm} / \mathrm{yr}$ in the north, only $12 \mathrm{~m} . \mathrm{y}$. are required to account for the missing $60 \mathrm{~km}$ on the northern part. In other words, if the northern Dead Sea fault system had been active for the entire 20 m.y. that the southern segment has, then large unrecognized offsets exist. Such offsets would probably be difficult to map along the northern Dead Sea faults where young volcanics and sediments obscure geologic structure [Quennell, 1984] and where the Dead Sea system bifurcates and becomes complex. Miocene and younger offsets on the southern Dead Sea faults are seen in Precambrian, Triassic, and Jurassic rocks [Courtillot et al., 1987] that strike obliquely to the fault. These offsets are thus inherently easier to map than would be offsets on the northern segment where strata strike at a much lower angle to the N-S trending faults. Accepting a maximum of $25 \mathrm{~km}$ of recognized displacement, a further $60 \mathrm{~km}$ of displacement on the northern segment of the Dead Sea fault system may still remain uncharted.

\section{Pre-Pliocene Independence of Northern and Southern Dead Sea Fault Segments}

The final remaining model that can account for the missing $60 \mathrm{~km}$ is depicted in Figure 9. Figure 9 shows a scenario in which slip along the northern Dead Sea fault system was not initiated before $6 \mathrm{Ma}$. This implies that there are indeed only $45 \mathrm{~km}$ of convergence to account for in northern Syria, 20-25 km in the Palmyrides and the acknowledged $20-25 \mathrm{~km}$ on the northern segment of the Dead Sea transform fault. In this last case, the northern and southern segments of the Dead Sea fault system functioned independently until the Early Pliocene (5-6 Ma.). The Roum fault in southern Lebanon, the seaward splay off the southern Dead Sea fault in Figure 9, may represent the extinct northward extension of the Miocene Dead Sea transform 
fault.

Paleomagnetic data from the Levant [Van Dongen et al., 1967; Zijderveld and Van der Voo, 1973] bear out this tectonic model. Sparse volcanic samples from this region indicate as much as a $28^{\circ}$ counterclockwise rotation of the Levant relative to Africa since the Lower Cretaceous. Since that time the Arabian platform has rotated in the same sense only $7^{\circ}$ relative to Africa. The excess rotation of the Levant, most of which can be taken as post-Cretaceous based on the timing of the major regional tectonism, may be attributable to a poor statistical sampling of rocks [Van Dongen et al., 1967] or it may in part represent a real counterclockwise rotation of northern Lebanon and northwestern Syria as depicted in Figure 10. Certainly more in-depth paleomagnetic studies need to be completed before great confidence can be placed in such a model; however, the simplicity of such a model holds considerable appeal.

\section{Summary}

In view of the four very different and in some cases mutually exclusive models proposed, some discussion of the viability of each is required. After examining closely all the models, only two of the four possibilities remain viable, that strike-slip faults accommodate some shortening or that the apparent $80 \mathrm{~km}$ of expected shortening is illusive, and the northern and southern segments of the Dead Sea system developed independently.

First, the improbable models must be discounted. Clearly the first possibility, that this balanced cross section study is wrong, is undesirable. For reasons already discussed, including mutually consistent results throughout the $400 \mathrm{~km}$-long belt, and confidence in the assumption of two-dimensional deformation, this possibility is unlikely. Equally unlikely is the possibility that the reliable scientists who for years scrutinized the northern Dead Sea fault system in aerial and satellite images and in the field [Ponikerov et al., 1963; Trifonov et al., 1983; Quennell, 1984;] missed tens of kilometers of left-lateral offset. Discounting these two scenarios leaves only two viable models to explain the shortening measurements which are seemingly inconsistent with other observations in the region.

Strike slip surely plays a role in accommodating shortening in the Palmyrides and northern Syria, but to what extent is unknown. Evidence of strike-slip faulting is readily observed in the field, but so is thrust faulting. The magnitude of strike slip in the Palmyrides, while significant, remains to be quantified. Strike slip must explain at least some of the observed enigma.

The only other viable model of those proposed is that the main left-lateral movement on the northern segment of the Dead Sea fault system was initiated only after the southern segment, including the Roum fault, had accrued about $60 \mathrm{~km}$ of pre-Pliocene offset. While paleomagnetic data support this model, these data unfortunately are few and so perhaps not per se convincing. Nevertheless, this model is intriguing and is attractive in its simplicity.

\section{CONCLUSIONS}

This study presents a quantitative measure of the magnitude of shortening in the Palmyride fold belt in Syria, based primarily on newly available seismic reflection data. The study also presents several models that account for the apparent discrepancy in observed left-lateral offsets across the northern versus the southern Dead Sea transform fault system as well as an examination of the viability of each model.

The Dead Sea system shows evidence of over $105 \mathrm{~km}$ of left-lateral displacement on its southern segment yet only $25 \mathrm{~km}$ on its northern segment, leaving an apparent $80 \mathrm{~km}$ of crustal movement unaccounted for. Palinspastically restored cross sections through the Palmyride fold belt in Syria show that at least $20 \mathrm{~km}$ of the "missing" $80 \mathrm{~km}$ is accommodated by thrusting and folding in the southwestern Palmyrides. At least four possibilities can explain the still elusive $60 \mathrm{~km}$ of crustal shortening in northern Arabia. The $20 \mathrm{~km}$ predicted by the retrodeformable cross sections may be almost a factor of four lower than actual shortening in the Palmyrides, but, because we estimate a present-day $\sim 40 \mathrm{~km}$ thick crust, this would necessitate the existence of unreasonably thin crust prior to shortening. The very rare occurrence of volcanic rocks in the Palmyrides would seem to preclude such a thin crust. If the balanced cross sections are accepted as yielding at least a grossly accurate estimate of shortening, then three possibilities remain. (1) Distributed strike slip in northern Syria 
accounts for 80 kilometers of NE-SW strike-slip motion, which has not been observed. New focal mechanisms support observations of strike slip in the field, so some as yet undetermined amount of strike slip must exist in the Palmyrides. (2) There remain 60 kilometers of uncharted left-lateral slip on the northern segment of the Dead Sea transform, a very unlikely possibility. (3) The northern and southern segments of the Dead Sea fault system moved, at least during Miocene time, independently, as Quennell [1958] suggested. In other words, the northern segment of the Dead Sea transform fault system is much younger than the southern part, and there are only 45 kilometers of crustal convergence expressed in northern Syria.

Documented strike-slip motion in the Palmyrides immediately lends support to the hypothesis that strike-slip motion accommodates at least some of the remaining displacement. In addition, an intriguing possibility introduced by Quennell [1958] is that the northern segment of the Dead Sea fault system was not coupled to the southern segment prior to the Pliocene. This would mean the $80 \mathrm{~km}$ of "missing" displacement is illusive, and that there really has been a total of only $45 \mathrm{~km}$ of N-S shortening in Syria. The truth likely lies in some combination of these two models.

Acknowledgments. Partial funding for this research was provided by Amoco, ARCO, Exxon, Marathon, and Unocal oil companies. Thanks are due Bob Litak, Art Barnes, and especially John Best for their thought provoking discussions, and R. Allmendinger, D. E. Karig, C. De Paor, and one anonymous reviewer for their critical reviews of the manuscript. Our appreciation is extended also to Robin Adams for providing important seismological data. Institute for the Study of the Continents at Cornell University contribution 125.

\section{REFERENCES}

Ben-Menahem, A., A. Nur, and M. Vered, Tectonics, seismicity and structure of the AfroEurasian junction-The breaking of an incoherent plate, Phys. Earth Planet. Inter., 12, 1-50, 1976.

Best, J. A., M. Barazangi, D. Al-Saad, T. Sawaf, A. Gebran, Bouguer gravity trends and crustal structure of Palmyride mountain belt and surrounding northern Arabian platform in Syria, Geology, in press, 1990.

Beydoun, Z. R., Some open questions relating to the petroleum prospects of Lebanon, J. Pet. Geol., 3, 303-314, 1981.

Burke, K. and C. Sengör, Tectonic escape in the evolution of the continental crust, in Reflection Seismology: The Continental Crust, Geodynamics Series, vol. 14, edited by M. Barazangi and L. Brown, pp. 41-53, AGU, Washington, D. C., 1986.

Courtillot, V., R. Armijo, P. Tapponnier, Kinematics of the Sinai triple junction and a twophase model of Arabia-Africa rifting, in Continental Extensional Tectonics, Spec. Publ. 28, edited by M. P. Coward, J. F. Dewey, and P. L. Hancock, pp. 559-573, Geological Society of London 1987.

Dahlstrom, C. D. A., Balanced cross sections, Can. J. Earth Sci., 6, 743-757, 1969.

De Paor, C., Balanced section in thrust belts part I: Construction, Am. Assoc. Pet. Geol. Bull.,72, 73-90, 1988.

Elliott, D., The construction of balanced cross-sections, J. Struct. Geol., 5, 101, 1983.

Freund, R., Z. Garfunkel, I. Zak, M. Goldberg, T. Weissbrod, and B. Derin, The shear along the Dead Sea rift, Philos. Trans. R. Soc. London, 267, 107-130, 1970.

Hempton, M., Constraints on Arabian plate motion and extensional history of the Red Sea, Tectonics, 6, 687-705, 1987.

Hossack, J. R., The use of balanced cross-sections in the calculation of orogenic contraction: a 
review, J. Geol. Soc. London, 136, $\overline{7} 05-711,1979$.

Jackson, J. and D. McKenzie, The relationship between plate motions and seismic moment tensors, and the rates of active deformation in the Mediterranean and Middle East, Geophys. J., 93, 45-73, 1988.

Le Pichon, X., and J. Francheteau, A plate-tectonic analysis of the Red Sea-Gulf of Aden area, Tectonophysics, 46, 369-406, 1978.

Lovelock, P. E. R., A review of the tectonics of the northern Middle East region, Geol. Mag., 121, 577-587, 1984.

McBride, J., M. Barazangi, J. Best, D. Al-Saad, T. Sawaf, M. Al-Otri, A. Gebran, Seismic reflection structure of the intracratonic Palmyride fold-thrust belt and surrounding Arabian platform in Syria, Am. Assoc. Pet. Geol. Bull., 74, 238-259, 1990.

Mount, V. S., and J. Suppe, State of stress near the San Andreas Fault: Implications for wrench tectonics, Geology, 15, 1143-1146, 1987.

Ponikerov, V. P. (Ed.), The Geological Map of Syria, scale 1:200,000, Ministry of Industry, Damascus, Syria, 1963.

Ponikerov, V. P., V. G. Kazmin, I. A. Mikhailov, A. V. Razvaliayev, V. A. Krasheninnikov, V. V. Kozlov, E. D. Soulidi-Kondratiyew, and V. A. Faradzhev, Explanatory notes, The Geological Map of Syria, scale 1:1,000,000, 111 pp., Ministry of Industry, Damascus, Syria, 1966.

Ponikerov, V. P., V. G. Kazmin, I. A. Mikhailov, A. V. Razvaliayev, V. A. Krasheninnikov, V. V. Kozlov, E. D. Soulidi-Kondratiyew, K. Ya. Mikhailov, V. V. Kulakov, V. A. Faradzhev, and K. M. Mirzayev, Explanatory notes Part I, The Geological Map of Syria, scale 1:500,000, 230 pp., Ministry of Industry, Damascus, Syria, 1967.

Quennell, A. M., The structural and geomorphic evidence of the Dead Sea Rift, Q. J. Geol. Soc. London, 114, 1-24, 1958.

Quennell, A. M., The western Arabian rift system, in The Geological Evolution of the Eastern Mediterranean, Spec. Publ. 17, edited by J. F. Dixon and A. H. F. Robertson, pp. 775-788, Geological Society of London, 1984.

Snoke, A. W., S. Schamel, and R. M. Karasek, Structural evolution of Djebal Debadib anticline: A clue to the regional tectonic style of the Tunisian Atlas, Tectonics, 7, 497-516, 1988.

Suppe, J., Principles of Structural Geology, Prentice Hall, Englewood Cliffs, New Jersey, 1985.

Trifonov, V., A. Youssef, Y. al-Khair, and T. Zaza, Using satellite imagery to infer the tectonics and the petroleum geology of Syria, report, p. 1-18, Syrian Petroleum Company, Damascus, Syria, 1983.

Van Dongen, P. G., R. Van der Voo, and T. Raven, Paleomagnetism and the Alpine tectonics of Eurasia, part III, paleomagnetic research in the Central Lebanon Mountains and in the Tartous area (Syria), Tectonophysics, 4, 35-53, 1967.

Walley, C. D., A braided strike-slip model for the northern continuation of the Dead Sea Fault and its implications to Levantine tectonics, Tectonophysics, 145, 63-72, 1988.

Woodcock, N. H., Strike-slip duplexes, J. Struct. Geol., 8, 725-735, 1986. 


\section{1}

Zijderveld, J. D. A. and R. Van der Voo, Paleomagnetism in the Mediterranean area, in Implications of Continental Drift to the Earth Sciences, vol. 1, edited by D. H. Tarling and S K. Runcorn, pp. 133-161, Academic, San Diego, Calif., 1973.

Zoback, M. D., M. L. Zoback, V. S. Mount, J. Suppe, J. P. Eaton, J. H. Healy, D.

Oppenheimer, P. Reasenberg, L. Jones, C. B. Raleigh, I. G. Wong, O. Scotti, and C.

Wentworth, New evidence on the state of stress of the San Andreas fault system, Science, 238, 1105-1111, 1987.

\section{Figure Captions}

Fig. 1a. Generalized geographic and tectonic setting of Syria showing locations of transects A, B, and C (see Plate 1 and Figures 2 and 3) in the Palmyride fold belt. Enlargement of boxed area is shown in Figure $1 b$.

Fig. 1b. Map view locations of the three cross sections A, B, and C and wells used in the study. Cretaceous outcrop is shaded and reflects the occurrence of structural highs. Detailed lithologic contacts are shown on the cross sections in Plate 1 and Figures 2 and 3. Stars represent epicenters of earthquakes discussed in text, and focal mechanisms of these two events are shown on lower hemisphere projections with compressional quadrants shaded.

Plate 1. (a) Interpretive line drawing of seismic data for transect A. (b) Balanced cross section of transect A. (c) Restored cross section of transect A. Shading of the strata is schematic only and not meant to imply lithology.

Fig. 2. (a) Interpretive line drawing of seismic data for transect B. (b) Balanced cross section of transect B. (c) Restored cross section of transect B. Shading of the strata is schematic only and not meant to imply lithology.

Fig. 3. (a) Interpretive line drawing of seismic data for transect C. (b) Balanced cross section of transect C. (c) Restored cross section of transect C. Shading of the strata is schematic only and not meant to imply lithology.

Fig. 4. An example of Lower Triassic (?) décollement in the southwestern Palmyrides decoupling relatively undeformed Paleozoic rocks from overlying Mesozoic strata. The location of this excerpt from cross section A is shown in Figure 1b. The seismic manifestation of the Jhar fault occupies the left-most part of the section.

Fig. 5. An example from the northeastern Palmyrides showing no evidence of a décollement surface. Paleozoic strata are involved in the deformation. The location of this excerpt, part of cross section $\mathrm{C}$, is shown in Figure $1 \mathrm{~b}$.

Fig. 6. Map views showing two end member ways in which the zone between the Arabian and Eurasian plates could respond to convergence: (a) thrusting and folding parallel to convergence; (b) strike slip oblique to convergence [modified from Courtillot et al., 1987].

Fig. 7. An example from the northern Aleppo plateau showing interpretation of a typical flower structure such as commonly results from strike-slip motion. The location of this excerpt is shown in Figure 1a.

Fig. 8. A possible model that invokes distributed strike slip to accommodate excess shortening [modified from Walley, 1988]. This model requires a total of about $80 \mathrm{~km}$ of NESW strike-slip motion.

Fig. 9. One possible kinematic model to explain the apparent discrepancy between left-lateral offsets observed on the segments of the northern versus the southern Dead Sea fault system. The Roum fault may have been the main northward continuation of the Dead Sea system 
12

during the Miocene. Displacements shown are net displacements. 